\title{
Economic Development from New Generation and Transmission in Wyoming and Colorado
}

New investments in power generation and transmission infrastructure provide opportunities for short- and long-term economic development. Opportunities are primarily in the states and localities where facilities are sited, as well as in those regions that manufacture equipment for the power sector. Wyoming's high quality wind resource and Colorado's clean energy manufacturing base offer noteworthy potential for new economic development activity resulting from wind and related power sector investments.

This factsheet summarizes a recent analysis, commissioned by the Wyoming Infrastructure Authority (WIA), that quantifies the gross jobs and economic development impacts that could result from the development of a $900 \mathrm{MW}$ wind power plant and a $225 \mathrm{MW}$ natural gas-fired power plant, both located in southeast Wyoming, and a 180-mile transmission line originating in southeast Wyoming and terminating in northeast Colorado.

\section{Methodology}

This work relies on the suite of NREL models known as the Jobs and Economic Development Impacts (JEDI) models: JEDI Wind, JEDI Natural Gas, and JEDI Transmission models were used in this analysis. JEDI models utilize input-output data from the Minnesota IMPLAN Group and default values that are based on interviews with industry experts and project developers.

JEDI models calculate three types of impacts: project development and onsite impacts, local revenue and supply chain impacts, and induced impacts. Onsite impacts are those that arise directly as a result of expenditures. These include project developers as well as operations and maintenance personnel. Local revenue and supply chain impacts are those that arise to serve the onsite developer or operator. These primarily include contractual service providers, manufacturers, and material providers. Induced effects arise from expenditures made by onsite workers as well as supply chain workers. These can include expenditures at local entertainment venues, child care, and retail sales. Estimates from JEDI are gross economic impacts and jobs are reported as full time equivalents (FTE).

\section{Modeling Inputs}

Based on the infrastructure development considered here-which is grounded in the proposed Wyoming-Colorado Intertie Project - the economies of both Wyoming and Colorado are affected. Accordingly, potential impacts to both states are analyzed. Table 1 details the total anticipated expenditures as well as the shares that are expected to flow through Wyoming and Colorado economies. During construction, an estimated $\$ 1.8$ billion is spent with about 80\% remaining in Wyoming and Colorado. During operations, an estimated $\$ 65$ million in ongoing annual expenditures are projected to support operations and maintenance activities. About $27 \%$ of total operations expenditures are estimated to remain in the two-state region.

For the purposes of this study, financing from outside of the Wyoming and Colorado region was assumed. Accordingly, debt, equity, and interest payments from project revenues are not considered in the economic assessment. Nevertheless, if a portion of the financing was provided by Colorado or Wyoming shareholders or debt providers, additional revenues and economic impacts could result. Premising a potential 9.25\% return on capital for a $50 \%$ equity share could result in more than $\$ 150$ million in additional income over a 20-year financing period. Were such income reinvested or spent locally, the resulting economic effects would be above and beyond those captured in this study.

Table 1. Anticipated Project Expenditures (\$ millions) and Local Shares

\begin{tabular}{|c|c|c|c|c|c|c|}
\hline \multirow[b]{2}{*}{ Project } & \multicolumn{3}{|c|}{ Construction Phase } & \multicolumn{3}{|c|}{ O\&M Phase } \\
\hline & Installed Cost & $\begin{array}{l}\text { Expenditures } \\
\text { in Wyoming }\end{array}$ & $\begin{array}{l}\text { Expenditures } \\
\text { in Colorado }\end{array}$ & $\begin{array}{l}\text { Annual O\&M } \\
\text { Expenditures }\end{array}$ & $\begin{array}{l}\text { Expenditures } \\
\text { in Wyoming }\end{array}$ & $\begin{array}{c}\text { Expenditures } \\
\text { in Colorado }\end{array}$ \\
\hline Transmission & $\$ 200$ & $26 \%$ & $25 \%$ & $\$ 7$ & $25 \%$ & $25 \%$ \\
\hline Gas* & $\$ 280$ & $27 \%$ & $12 \%$ & $\$ 41$ & $5 \%$ & $1 \%$ \\
\hline Wind & $\$ 1,350$ & $18 \%$ & $77 \%$ & $\$ 17$ & $29 \%$ & $42 \%$ \\
\hline Total Local & & $\$ 370$ & $\$ 1,100$ & & $\$ 9$ & $\$ 9$ \\
\hline
\end{tabular}

*Note: Natural gas fuel expenditures are not included in local content. 


\section{Results}

Construction of the three projects is estimated to support approximately 12,000 jobs, or an average of 4,000 annually over an estimated three-year construction period. Table 2 illustrates the relative impact of the specific infrastructure investments as well as the distribution among the types of impacts reported. The majority of construction labor impacts are expected in turbine, power generation, and equipment supply chain — significantly more labor is required to manufacture capital-intensive wind components than to install them. These results are contingent on turbine components being manufactured in Colorado while purchases of other basic construction materials and labor are assumed to be split between Colorado and Wyoming. Workers supported by the construction of these projects are estimated to earn approximately $\$ 69,000$ annually.

Table 2. Annual Average Jobs Related to Construction Over the Three-Year Construction Period

\begin{tabular}{l|c|c|c|c|c}
\multirow{2}{*}{} & \multicolumn{3}{|c|}{ Annual Average } & Cumulative \\
\cline { 2 - 7 } & Transmission & Gas & Wind & Total & Total \\
\hline Project development and onsite labor & 350 & 170 & 180 & 700 & 2,100 \\
\hline Turbine, power generation, and equipment supply chain & 90 & 70 & 2,250 & 2,400 & 7,210 \\
\hline Induced - local expenditures & 70 & 70 & 740 & 880 & 2,650 \\
\hline Total & 500 & 320 & 3,160 & 3,990 & 11,970 \\
\hline
\end{tabular}

Note: Totals may not sum due to rounding.

Nearly 400 long-term jobs are estimated to be supported each year that the proposed projects operate (Table 3), about 75\% of these jobs in Wyoming and about 25\% in Colorado. Half of these are involved in the supply chain, which includes lease payments to landowners as well as the production and assembly of replacement parts for the facilities' equipment. Annual average compensation of jobs supported by operations and maintenance is estimated at $\$ 50,000$ per job.

Table 3. Long-Term Jobs Related to Operations and Maintenance

\begin{tabular}{l|c|c|c|c|} 
& Transmission & Gas & Wind & Total \\
\hline Onsite labor impacts & 40 & 10 & 40 & 160 \\
\hline Local revenue and supply chain impacts & 20 & 20 & 70 & 100 \\
\hline Induced - local expenditures & 20 & 10 & 270 & 390 \\
\hline Total & 70 & 40 & \\
\hline
\end{tabular}

Note: Totals may not sum due to rounding.

Total economic activity (output) to the combined region is estimated at $\$ 2.4$ billion during the projects' construction and approximately $\$ 70$ million annually during operations. Total economic activity (output) to the combined region is estimated at $\$ 2.4$ billion during the projects' construction and approximately $\$ 70$ million annually during operations. Assuming a 20 year life for these facilities, the total cumulative gross economic output is estimated at $\$ 3.7$ billion.

These results suggest that such investments could have notable impacts on the economies of both Colorado and Wyoming, with Colorado being more greatly affected during construction and Wyoming seeing the majority of the impacts during operations. Changes in underlying economic and electricity sector market conditions, as well as changes in the local purchasing and procurement patterns, are the primary sources of uncertainty that could cause actual impacts to deviate from these estimates. The results from this study are generally consistent with impacts observed elsewhere in the literature and reported by communities that have experienced wind power development activity in Colorado, lowa, Minnesota, Texas, and elsewhere.

For additional detail on the analysis inputs and results, please see the full report of estimated economic development impacts from new generation and transmission in Wyoming and Colorado, available as a PDF from http://www.nrel.gov/docs/fy13osti/57411.pdf. 